\title{
Token economi untuk menurunkan perilaku agresif pada anak Gangguan Pemusatan Perhatian dan/atau Hiperaktivitas
}

\author{
Inastasya, Universitas Muhammadiyah Malang, Malang, Indonesia
}

Korespondonesi:

Inastasya, Universitas Muhammadiyah Malang, e-mail: inastasya.spsi@gmail.com

\begin{abstract}
Riwayat artikel Naskah diterima: $04 / 10 / 2017$
\end{abstract}

Revisi diterima: $06 / 12 / 2017$

Naskah disetujui: $15 / 12 / 2017$

\begin{abstract}
Abstrak
Klien (L/9 tahun) saat ini sekolah di SDLB kelas 1.Perilaku klien ketika di sekolah, dimana klien sering menganggu temannya seperti menjahili sampai memukul temannya.Asesmen yang dilakukanmenggunakan wawancara, observasi, Tes WISC, Grafis, CBCL dan ADHD rating scale. Hasil asesmen didapatkan bahwa perilaku memukul klien didapatkan dari proses belajar dan mendapatkan penguatan sehingga perilaku tersebut diulang terus menerus. Klien memiliki gangguan GPPH dengan permasalahan saat ini yaitu perilaku memukul orang lain. Intervensi yang digunakan menggunakan token economic.Hasil intervensi didapatkan bahwa adanya penurunan perilaku memukul klien dari tiga kali memukul menjadi 1 kali memukul dalam sehari. Kata kunci: Token Economic, Perilaku Memukul, GPPH
\end{abstract}

\section{Latar Belakang}

Gangguan pemusatan perhatian dan/atau hiperaktivitas (GPPH) adalah gangguan perkembangan dalam peningkatan aktivitas motorik anak-anak sehingga menyebabkan aktivitas anak-anak yang tidak lazim dan cenderung berlebihan.Anak GPPH menunjukkan berbagai keluhan yaitu seperti perasaan gelisah, tidak bisa diam, tidak bisa duduk dengan tenang dan selalu meninggalkan keadaan yang tetap seperti sedang duduk atau sedang berdiri. Beberapa gejala lain yang sering terlihat adalah suka meletup-letup, aktivitas berlebihan dan suka membuat keributan. Tiga gejala pokok yang sering terlihat pada anak GPPH adalah kesulitan memusatkan perhatian, hiperaktivitas dan impulsivitas (APA,2013).

Perilaku yang sering terjadi pada anak adalah perilaku agresivitas. Perilaku agresivitas dapat didefinisikan sebagai perilaku yang terlihat yang dapat mengakibatkan kerugian bagi diri sendiri atau orang lain (Sukhodolsky et al., 2016). Karakteristik perilaku agresif yaitu seperti memukul, mencubit, mengejek, dan mengolok-olok merupakan perilaku yang tidak diharapkan 
oleh guru, karena perilaku agresif ini mengganggu proses belajar, dapat mengganggu siswa lain dan juga menakuti siswa lain (Handayani \& Hidayah, 2014)

Perilaku agresivitas menjadi bagian dari tahapan perkembangan mereka dan sering kali menimbulkan masalah, baik itu di rumah, sekolah ataupun dalam suatu kelembagaan yang mana disuatu tempat tersebut dia dapat berinteraksi terutama dengan orang lain. Perilaku agresivitas pada anak-anak telah terbukti memiliki kemampuan verbal yang lemah, keterampilan resolusi konflik yang buruk, dan defisit dalam keterampilan pertemanan (Sukhodolsky,2016).

Menurut Soekadji (1983) gejala agresivitas termasuk perilaku-perilaku yang menyimpang dan merupakan masalah pribadi, yang dapat ditangani dengan memanfaatkaan prinsip-prinsip proses belajar. Ada beberapa cara dalam mengurangi perilaku agresif dengan modifikasi perilaku untuk mengurangi perilaku agresif, seperti pemberian reward, punishment, time out, dan juga token ekonomi atau tabungan kepingan (Erianny \& Marlina, 2017). Menurut Soekadji (1983) gejala agresivitas merupakan salah satu perilaku yang dapat diturunkan dengan pemberian token ekonomi.

Token ekonomiadalah prosedur pemberian satu kepingan (satu tanda atau isyarat) sesegera mungkin setelah perilaku yang diharapkan muncul, dan kepingan ini nantinya dapat ditukar dengan benda atau aktivitas yang diinginkan subjek (Handayani \& hidayah, 2014). Pemberian intervensi didasari karena seringnya anak mengganggu teman yaitu dengan cara mudah marah, memukul teman, mendorong teman, berkelahi, menganggu teman dan mengejek teman. Hal ini juga karena selama ini guru sudah kehabisan cara dalam menasehati anak, Perilaku yang menonjol pada anak adalah memukul, menganggu teman dan suka berkelahi. Hal ini diperkuat oleh pendapat guru kelas dan guru-guru serta orangtua klien bahwa klien adalah siswa yang susah di atur karena sering berjalan dikelas, mudah marah, suka mengganggu teman dan berkelahi.

Pemberian token ekonomidalam intervensi ini tertujuan untuk mengurangi perilaku memukul anak ketika di sekolah.Pemberian token ekonomi di sekolah didasari karena perilaku memukul klien lebih sering terjadi ketika di sekolah. Token ekonomimerupakan usaha mengembangkan perilaku, bisa dalam bentuk merubah, mengurangi, dan menambah sesuai dengan tujuan yang diharapkan dengan menggunaan penghargaan. Setiap individu mendapat penghargaan setelah menunjukan perilaku yang diharapkan atau perilaku target (Saroha \& Marlina, 2017).

\section{Metode Asesmen}

Wawancara klinis dan Observasi, menggunakan alat tes psikologi berupa tes intelegensi yaitu WISC dan tes Grafis. Observasi bertujuan untuk melihat kondisi klien, taraf keberfungsian dan status mental.Wawancara klinis dilakukan untuk mengetahui riwayat terbentuknya permasalahan klien dan menggali informasi pada significant others terkait perkembangan klien. Tes WISC ( Wechlers Intellegence Scale for children) diberikan guna menganalisa sejauh mana keterbatasan intelektual yang dimiliki klien serta IQ-nya. Tes Grafis (DAP, BAUM dan HTP) bertujuan untuk mengungkap aspek emosi, sosial maupun kognitif klien.CBCL (Child behavior Checklist) untuk mengetahui perilaku anak sehari-hari berdasarkan observasi orangtua dan guru. ADHD rating scale menurut DSM-IV untuk mengetahui tingkat keparahan gangguan ADHD yang diderita anak.

\section{Presentasi Kasus}

Klien merupakan anak laki-laki usia 7 tahun dan saat ini bersekolah di SLB di Malang. Pada masa kehamilan klien, perkembangan masa kehamilan normal dan proses kelahiran berjalan normal. Usia kandungan ketika hamil klien berusia 7 bulan dengan lahir prematur dan berat bayi $2,2 \mathrm{~kg}$ dan panjang $42 \mathrm{~cm}$. Perkembangan pada masa balita klien, klien mendapatkan ASI (air susu ibu) secara ekslusif sampai usia 2 tahun dan tidak memiliki kesulitan dalam makanan. 
Ketika klien usia 1 tahun klien mengalami kejang dan di rawat di ICU beberapa hari. Setelah kejadian tersebut, klien mengalami kemunduran baik dalam kognitif, emosi maupun sosial.Perkembangan fisik klien pada masa balita, klien dapat berdiri pada usia 3 tahun, dapat berjalan pada usia 4 tahun, mampu naik sepeda roda tiga pada usia 5 tahun namun belum bisa mengendarai sepeda roda dua. Klien mulai berceloteh pada usia 3 tahun kemudian sudah mampu berbicara dengan satu kata bermakna pada usia 4-5 tahun serta berbicara dengan kalimat lengkap pada usia 5 tahun, namun sampai sekarang kalimat yang diucapkan tidak jelas pelafalannya tetapi mampu di pahami oleh orang lain.

Klien saat ini tinggal dengan nenek dan kedua orangtua nya.Orangtua klien bercerai dan saat ini klien tinggal dengan ibu kandung dan ayah sambung.Ibu dan ayah sambung baru menikah sekitar tahun 2016.Ketika di lingkungan rumah, nenek mengatakan bahwa klien sering marah-marah dan terkadang memukul orang seperti ayah, ibu maupun neneknya.Ketika berbicara dengan klien teradang nenek sering menggoda karena klien tidak bisa berbicara dengan jelas.Ketika digoda klien terkadang memukul neneknya ataupun ketika klien mulai bingung karena oranglain tidak memahami perkataannya klien terkadang memukul kepalanya sendiri dan menangis. Kebiasaan klien di rumah yaitu klien sering menonton kartun seperti kartun "Thomas and Friends" dan "Tayo bis kecil". Selain itu klien sering memain gimbot dan terkadang melihat video lewat HP ibu atau ayah. Kemudian setiap pagi klien dan ayahnya sering pergi ke stasiun kereta untuk melihat kereta api. Klien sengat menyukai kereta api karena cita-citanya ingin menjadi masinis.

Ayah dan ibu klien baru menikah pada tahun 2017. Sejak ibu klien bercerai, klien diasuh oleh nenek.Kakek klien sudah meninggal.Ibu klien bekerja dari pagi sampai sore dan hanya mempunyai waktu sebentar dengan klien.Klien dirumah sering bersama dengan ayah dan neneknya. Ketika sore klien mengikuti pembelajaran mengaji di Musholah dekat rumahnya dan terkadang bermain bersama dengan teman-teman yang lain ketika selesai mengaji.

Ketika di sekolah, klien terkadang suka jahil kepada teman-temannya.Teman-teman yang sering di ganggu yaitu teman yang tidak berani melawan ataupun yang memiliki disabilitas dalam berbicara.Ketika di sekolah, klien cenderung mudah marah, sering berkelahi dengan temannya dan memukul ataupun mengigit temannya ketika sedang marah.Ketika diminta untuk meminta maaf, klien terkadang mau dan terkadang tidak mau minta maaf. Klien cenderung cepat melupakan amarahnya ketika dialihkan dengan kegiatan atau barang yang lain.

Klien mulai masuk TK pada usia 5 tahun. Lama pendidikan klien ketika di TK selama 2 tahun. Kesulitan yang dialami oleh klien ketika di TK yaitu klien sulit untuk berkonsentrasi dan tidak mau duduk dengan tenang selain itu klien juga sering mudah marah dan memukul orang lain. Ketika memasuki Sekolah Dasar, klien masih sulit berkonsentrasi ketika pelajaran.Selain itu, klien masih sering mudah marah dan menyerang temannya seperti memukul dan berkelahi. Klien memiliki kendala dalam berbicara dimana ketika berbicara perkataan klien kurang jelas.Saat ini klien sudah menjalan terapi bicara dan sudah cukup mampu berbicara walaupun tidak terlalu jelas.Saat ini, klien memiliki teman dekat yang sering bermain bersama ketika disekolah. Teman dekat klien, merupakan anak yang tidak patuh dan sering menganggu teman yang lain.

Klien memiliki tingkat kecerdasan pada taraf lambat belajar dengan nilai skor IQ sebesar 79.Hal ini menandakan bahwa klien memiliki kapasitas intelegensi berada jauh dibawah anak-anak lain seusianya. Selain itu ia tidak mampu mengerjakan tugas yang diberikan tanpa bantuan ataupun bimbingan dari orang lain. Klien memiliki kendala pada soal ataupun permasalahan yang membutuhkan perhatian, konsentrasi dan ketelitian. Sehingga pada kesehariannya klien membutuhkan bimbingan dari orang lain dalam menyelesaikan tugas.

Selanjutnya dalam interaksi sosial, ia memiliki hambatan yang bisa diakibatkan oleh sifatnya yang impulsif dan mudah tersinggung sehingga kurang mampu menyesuaikan diri dalam 
lingkungan sosialnya Berdasarkan hasil CBCL, perilaku klien berkencederungan pada perilaku agresif. Berikutnya dari sisi emosinya, ia cenderung memiliki suatu dorongan kekuatan dalam mencapai sesuatu sehingga klien cenderung impulsif, dikuasai emosi dan tidak stabil.

Dinamika permasalahan klien dapat dijelaskan bahwa perilaku memukul, berkelahi dan menganggu teman merupakan sifat bawaan klien yang impulsif dan mudah tersinggung sehingga kurang mampu menyesuaikan diri dalam lingkungan sosialnya.Perilaku negatif klien yang suka memukul, berkelahi dan menganggu merupakan salah satu ciri perilaku agresif. Perilaku agresivitas dapat didefinisikan sebagai perilaku yang terlihat yang dapat mengakibatkan kerugian bagi diri sendiri atau orang lain (Sukhodolsky et al., 2016). Karakteristik perilaku agresif yaitu seperti memukul, mencubit, mengejek, dan mengolok-olok merupakan perilaku yang tidak diharapkan oleh guru, karena perilaku agresif ini mengganggu proses belajar, dapat mengganggu siswa lain dan juga menakuti siswa lain (Handayani \& Hidayah, 2014)

Ketika di sekolah anak memiliki teman yang dekat dan selalu bermain bersama. Kemudian anak memperhatikan temannya tersebut yang menganggu teman yang lain. Menurut teori behavior dimana gangguan perilaku yang terjadi karena pengalaman salah belajar (Wirmihardja, 2007).Pegalaman salah belajar yang dimaksud yaitu yaitu mempelajari dengan benar perilaku yang tidak baik atau mempelajari dengan salah contoh perilaku yang baik.Pada kasus klien, klien mampu mempelajari perilaku yang salah dari temannya.Klien memiliki kemampuan dalam mengamati dan menangkap perbedaan objek yang diamati. Sehingga klien dengan mudah menirukan perilaku temannya dengan menganggu teman atau memukul teman yang lain. Kemudian klien mendapat kesenangan ketika ia mampu membuat temannya menangis dan tidak membalas perbuatannya. Menurut Skinner hubungan antara stimulus dan respons yang terjadi melalui interaksi dengan lingkungannya, kemudian menimbulkan perubahan tingkah laku.Stimulus-stimulus yang diberikan akan saling berinteraksi dan interaksi antar stimulus tersebut yang mempengaruhi respons yang dihasilkan. Respons yang diberikan ini memiliki konsekuensi-konsekuensi.Konsekuensi-konsekuensi tersebut nantinya mempengaruhi munculnya perilaku (Slavin, 2000).

Pada saat di rumah perilaku memukul klien dibiarkan oleh orangtua dengan tidak menahan atau memarahi klien ketika ia memukul oranglain. Pembiaran yang dilakukan oleh orangtua dikarenakan orangtua dan nenek klien yang sangat memanjakan klien sehingga selalu menuruti perintah klien dan tidak pernah menahan ataupu memarahi ketika klien memukul orang.Selain itu ketika di sekolah, perilaku memukul klien dilakukan ketika guru tidak ada dan terkadang guru sering membiarkan klien untuk memukuli temannya dengan tidak memarahi atau menghiraukan klien. Perilaku agresivitas menjadi bagian dari tahapan perkembangan mereka dan sering kali menimbulkan masalah, baik itu di rumah, sekolah ataupun dalam suatu kelembagaan yang mana disuatu tempat tersebut dia dapat berinteraksi terutama dengan orang lain.

Pembiaran dari orangtua maupun guru membuat perilaku memukul tersebut bertahan dan selalu ada. Selain itu dengan adanya penguatan dari lingkungan sehingga perilaku yang dimunculkan semakin diperkuat.Bagi B.F. Skinner belajar adalah tingkah laku, dan tingkah laku tersebut dikontrol oleh penguatan stimuli yang mengikutinya (Skinner, 1953).Menurut Skinner perilaku agresif terbentuk karena perilaku tersebut mendapatkan penguatan positif dan perilaku tersebut akan diulang oleh individu untuk memperoleh penguatan kembali. Hal tersebut terjadi pada kasus klien dimana penguatan yang terjadi berasal dari pembiaran dari orangtua ataupun orang sekeliling klien serta pembelajaran perilaku yang salah dari teman klien yang sering berprilaku agresif di sekolah.

Pemberian intervensi pada kasus ini menggunakan token economic. Menurut Soekadji (1983) gejala agresivitas termasuk perilaku-perilaku yang menyimpang dan merupakan masalah pribadi, yang dapat ditangani dengan memanfaatkaan prinsip-prinsip proses belajar. Ada beberapa cara dalam mengurangi perilaku agresif dengan modifikasi perilaku untuk mengurangi 
perilaku agresif, seperti pemberian reward, punishment, time out, dan juga Token ekonomiatau tabungan kepingan (Erianny \& Marlina, 2017). Pemberian intervensi didasari karena seringnya anak mengganggu teman yaitu dengan memukul teman, berkelahi, dan menganggu teman. Perilaku yang menonjol pada anak adalah memukul sehingga perilaku tersebut yang akan jadi fokus intervensi. Dinamika psikologi pada subjek dapat dilihat pada Gambar 1

\section{Diagnosis dan Prognosis}

\section{Diagnosis}

Berdasarkan uraian kasus, hasil asesmen dan rujukan yang ada pada DSM-V (Diagnostic and statistical Manual Mental Disorder), maka ditegakkan diagnosis klien telah memenuhi kriteria diagnostik: code 314.01 (F90.2) Gangguan Pemusatan perhatian dan atau hiperaktivitas yang ditandai dengan perilaku hiperaktif seperti tidak mampu duduk diam dan sering berjalan-jalan

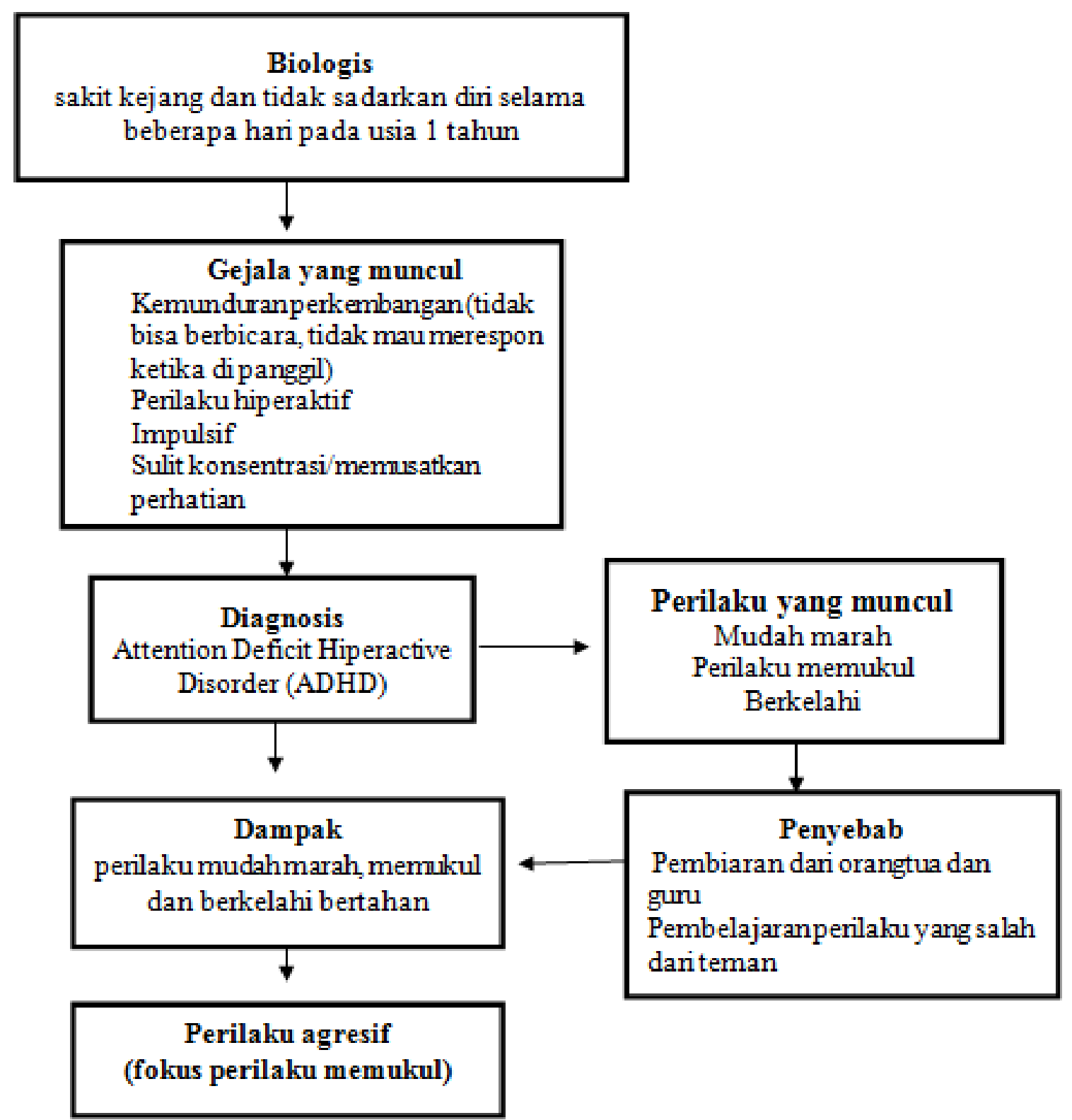

Gambar 1. Dinamika Psikologi. 
ketika dituntut untuk duduk, impulsif, sulit memusatkan perhatian (sulit konsentrasi) timbul sebelum anak usia 7 tahun dan perilaku agresif (memukul). Permasalahan GPPH yang dialami klien saat ini yaitu permasalahan perilaku maladaptif yaitu agresif dalam bentuk memukul oranglain.

\section{Prognosis}

Terapis memperkirakan keberhasilan klien dalam melakukan treatmen adalah baik.Hal ini dikarenakan klien memiliki dukungan keluarga dan lingkungan yang baik serta klien yang cukup kooperatif dan adanya dukungan teman-teman sekolah klien untuk memberikan stimulus pada klien.Serta adanya bantuan ayah dan guru yang membantu dalam proses intervensi untuk merubah perilaku klien.

\section{Intervensi}

Pada kasus ini terapis memberikan kegiatan intervensi berupa token ekonomiyang bertujuan untuk menurunkan perilaku agresif klien dalam bentuk memukul. Pemberian intervensi didasari oleh permasalahan utama klien yang bersifat urgent saat ini yaitu perilaku agresif yang selalu dimunculkan tiap hari ketika disekolah dan dirumah. Kemudian pemberian token ekonomicocok untuk diterapkan pada anak-anak yang masih membutuhkan dominasi atau bimbingan orang dewasa selain itu intervensi ini bersifat konkrit sehingga mudah di pahami oleh anak dimana ketika perilaku agesif dalam bentuk memukul tidak muncul dan mendapatkan reinforcement dan diberikannya token maka akan berpeluang untuk perilaku tersebut lebih sering terjadi (agar mendapat reinforcement yang diinginkan).

Intervensi yang diberikan menggunakan pendekatan behavior yang memiliki empat karakteristik diantaranya: a) berfokus pada perilaku, mencoba untuk memodifikasi perilaku yang defisit atau kelebihan perilaku; b) menganggap pembelajaran dan lingkungan sebagai sumber utama dimana perilaku dapat diubah; c) memiliki orientasi ilmiah yang kuat; dan, d)pendekatannya untuk mengubah perilaku adalah pragmatid dan aktif ( Sarafino, 2012).

Penerapan teknik-teknik perubahan perilaku mengasumsikan bahwa perilaku pada umumnya dapat dilakukan dan dapat dimodifikasi dengan memberikan pengalaman baru yang sesuai, dimana pengalaman baru yang digunakan dalam memodifikasi perilaku melibatkan mengubah aspek lingkungan individu ( Sarafino, 2012).

Token ekonomimerupakan salah satu teknik modifikasi perilaku dengan cara memberikan token (tanda) untuk meningkatkan perilaku positif dan menurunkan perilaku yang tidak diharapkan pada seseorang. Token adalah penguat yang dikondisikan yang seperti uang karena dapat diakmulasikan dan ditukar dengan barang atau hak istimewa, yang disebut backup reinforcers (Sarafino, 2012). Token dapat berupa stiker, kepingan plastik, tutup botol, tanda bintang, tanda lingkaran dan stempel.

Teknik token ekonomiini yang digunakan oleh terapis yaitu menggunakan kepingan berbentuk stempel yang dapat ditukarkan apabila anak berperilaku sesuai dengan yang diharapkan.Penukar koin tersebut berupa hadiah yang disiapkan oleh peneliti, disini peneliti menggunakan makanan seperti kue dan roti sebagai hadiah. Pemberian intervensi didasari karena seringnya anak mengganggu teman yaitu dengan cara mudah marah, memukul teman, mendorong teman, berkelahi, menganggu teman dan mengejek teman.

Target intervensi pada kasus ini yaitu mengurangi perilaku memukul anak dari perilaku memukul 3 kali dalam sehari menjadi 1 kali dalam sehari.Hal ini didasari oleh hasil data yang diperoleh terapis pada tahap baseline yang didapatkan dari observasi terapis ketika disekolah.

Adapun sesi pemberian token ekonomimenurut Sarafino (2012) adalah sebagai berikut.

Sesi 1: Identifikasi masalah dan menentukan perilaku target. Pada sesi ini terapis melakukan wawancara dan observasi dengan guru dan orangtua klien untuk menggali dan 
menentukan masalah serta perilaku target yang akan di ubah pada proses intervensi. Terapis memberikan skala CBCL kepada orangtua dan guru serta mengobservasi kegiatan anak ketika anak di sekolah.

Berdasarkan observasi yang dilakukan selama 5 hari, perilaku yang muncul ketika klien bermain dengan teman yaitu perilaku memukul.Perilaku memukul, biasanya terjadi ketika klien bermain dengan teman-temannya dan ketika keinginan klien tidak terpenuhi.Sehingga perilaku target yang ditentukan dalam intervensi ini yaitu perilaku klien dalam bentuk memukul.

Sesi 2: Pengambilan data dasar (Taking baseline). Pada sesi ini, terapis melakukan observasi pada perilaku klien dengan menggunakan behavior checklist untuk intensitas perilaku memukul klien ketika di sekolah dengan menggunakan checklist perilaku.Pengukuran dilakukan selama 5 hari dengan mencatat durasi dalam satuan hari yaitu berapa kali klien memukul orang ketika di sekolah.

Berdasarkan pengamatan terapisselama 5 hari didapatkan bahwa ketika disekolah, rata-rata perilaku memukul klien perhari yaitu sebanyak 3 kali memukul teman dalam sehari. Sedangkan dirumah, rata-rata perilaku memukul klien sekitar 1 kali memukul orang dalam sehari. Baselineperilaku memukul klien sebagaimana Gambar 2

Sesi 3: Menentukan token. Pada sesi ini terapis menentukan token yang akan digunakan (Selecting the type of token economy to use), memilih pengukuh cadangan (Selecting backup reinforcers), mengidentifikasi bantuan yang tersedia (identifying available help) dan memilih lokasi atau tempat (choosing the locations).

Token yang diberikan kepada klien yaitu berupa stempel hewan yang akan diberikan ketika perilaku yang dikendaki muncul. Pengukuhan yang diberikan yaitu berupa stempel yang akan di tempelkan di buku token yang sudah disiapkan oleh terapis. Pemberian stempel kepada anak dilakukan oleh terapis dan guru pendamping klien ketika di sekolah. Terapis memberikan penjelasan kepada orangtua, guru dan anak mengenai token ekonomiyang akan diberikan kepada anak.

Guru memahami penjelasan dari terapis dan memberikan respon dengan baik ketika diminta untuk membantu dalam proses intervensi. Selain itu, guru juga sudah memahami prosedur token ekonomikarena pernah memberikan kepada muridnya dulu.Orangtua memahami penjelasan terapis mengenai token ekonomi. Ketika mendiskusikan mengenai pengukuhan dan pemberi token, ibu lebih banyak memberikan masukan seperti menjelasakan bahwa anak suka ketika diberikan kue, melihat kereta api atau pujian.

Sesi 4: Menentukan prosedur pemberian token. Pada sesi ini terapis bertugas mendiskusikan prosedur pemberian token kepada klien, guru dan orang tua. Terapis menjelaskan

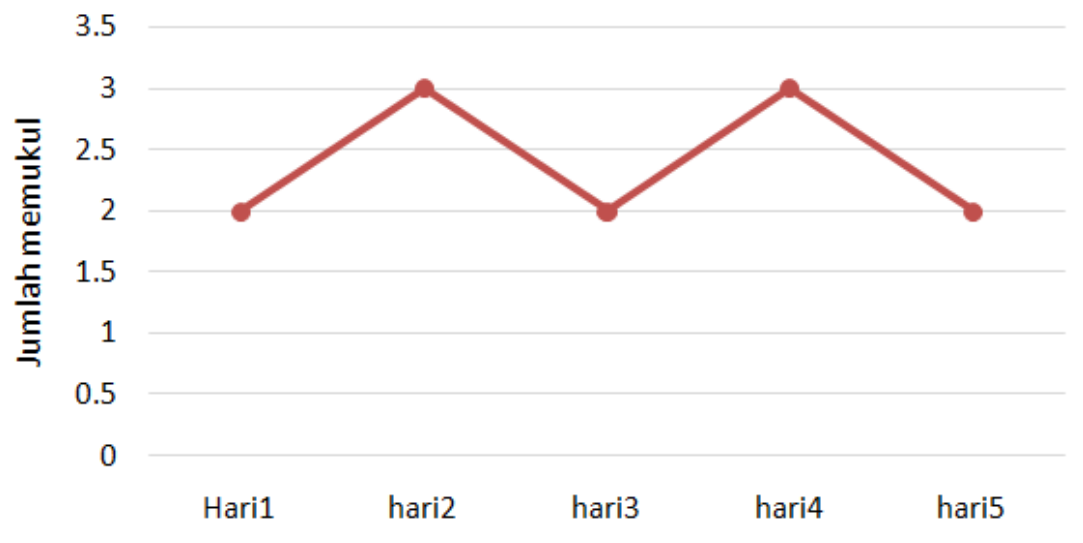

Gambar 2. Baseline perilaku memukul klien. 
mengenai hasil baseline yang sudah didapatkan dan target intervensi yang sudah ditentukan kepada orangtua dan guru. Ketika menjelaskan ayah dan guru menyimak dengan baik selama penjelasan berlangsung. Hasil diskusi didapatkan bahwa pemberian token dilakukan yaitu ketika klien tidak memukul orang lain di sekolah. Terapis memberikan stempel kepada guru klien serta buku tabungan stempel untuk tugas klien.

Norma pemberian token yaitu menggunakan interval tetap (fixed interval). Pemberian reinforcemen berselang selama 2 jam. Sehingga apabila klien tidak memukul oranglain sesuai batas yang ditetapkan (selama 2 jam) maka klien akan diberikan 1 stempel dan pujian. Tambahan 1 stempel apabila tidak menganggu atau berkelahi dengan teman. Hadiah kue akan diberikan ketika stempel terkumpul sampai 10 stempel.

Pada sesi ini, terapis menjelaskan norma kepada orangtua dan guru. Guru mengatakan bahwa ia paham karena pernah mendapatkan pelajaran token ekonomi juga.

Sesi 5: Evaluasi perubahan I. Pada sesi ini, terapis melakukan evaluasi kepada guru dan klien.Ketika disekolah, guru mengatakan perilaku anak sedikit berkurang.Seperti perilaku memukul hanya di dapatkan ketika klien berebutan mainan dengan temannya. Guru mengatakan ketika perasaan anak sudah buruk dari rumah lalu datang kesekolah, maka anak lebih cenderung suka memukul. Seperti ketika ia sedang bermain atau ketika teman klien ingin meminjam mainan kien maka klien akan langsung marah dan memukul temannya. Selain itu, guru mengatakan klien cukup bisa dikondisikan dan diingatkan bahwa perilaku memukul teman itu tidak baik.Sehingga ketika klien mulai marah atau menganggu temannya maka guru mengingatkan dan anak tidak jadi memukul temannya.

Evaluasi terapis dengan klien, klien mengatakan bahwa ia senang bermain dengan temannya. Selain itu, klien mulai bisa bermain bersama temannya yang lain tanpa berkelahi, ketika temannya mulai meminjam mainannya ia terkadang merasa risih namun tidak sampai memukul temannya. Perilaku memukul klien mengalami penurunan dari awalnya 3 kali menjadi 2 atau 1 kali memukul teman per hari.

Sesi 6: Evaluasi perubahan II. Pada sesi ini, terapis melakukan evaluasi dengan guru 4 hari setelah sesi berikutnya.Pada saat di sekolah guru mengatakan klien perilaku memukul klien sudah cukup menurun.Perilaku memukul yang menurun dibuktikan melalui berkurangnya perilaku memukul klien ketika di sekolah yang awalnya bisa 4 kali menjadi 2 atau 1 kali.Guru juga mengatakan bahwa klien masih sering menganggu teman namun tidak sampai memukul. Guru mengatakan bahwa ada beberapa anak tertentu yang masih diganggu dan di pukuli oleh klien namun tidak sesering dulu. Perilaku memukul klien mengalami penurunan. Klien mendapatkan reward berupa roti.

Sesi 7: Evaluasi dan Terminasi. Pada sesi ini, terapis melakukan evaluasi akhir dengan guru klien.Evaluasi akhir dilakukan 4 hari setelah sesi sebelumnya.Guru klien mengatakan bahwa ketika disekolah, perilaku memukul klien sudah berkurang dari yang awalnya 4 kali memukul berkurang menjadi 1 kali memukul.Hal tersebut biasanya terjadi ketika teman yang lain masih menganggu klien sehingga ia memukulnya. Guru mengatakan bahwa klien masih mudah marah namun sudah tidak memukul temannya. Terapis memberikan motivasi kepada klien, ayah klien dan guru klien untuk selalu konsisten untuk merubah perilaku klien.Dan menjelaskan bahwa intervensi sudah berakhir/dihentikan. Klien mendapatkan reward berupa kue dan roti cokelat.

Sesi 8: Follow Up. Sesi ini dilaksanakan 2 minggu setelah intervensi berakhir. Follow up dilaksanakan dengan mewawancarai guru pendamping klien dimana perilaku memukul klien menurun dimana sekitar sekali dalam sehari perilaku memukul muncul di sekolah. Guru juga mengatakan bahwa klien sudah mampu menahan emosinya dan tidak memukul oranglain walaupun diprovokasi atau diganggu oleh temannya. 


\section{Hasil dan Pembahasan}

\section{Hasil}

Intervensi dilakukan selama 9 Hari di sekolah.Hasil intervensi yang dilaksanakan ketika di sekolah dapat di lihat pada gambar 2.Pelaksanaan intervensi disekolah dilaksanakan selama 9 hari karena klien bersekolah 5 hari dimulai pada hari senin sampai jumat dan ketika intervensi berlangsung klien tidak masuk 2 hari karena sakit dan ijin.

Gambar 2. Hasil Perubahan Perilaku Memukul klien

Hasil intervensi menunjukkan bahwa klien mengalami penurunan frekuensi memukul.Pada awal intervensi klien belum mampu mengendalikan perilaku memukulnya disekolah.Hal tersebut dikarenakan klien masih suka menganggu teman sehingga berakhir pada pertengkaran. Kemudian peningkatan drastis pada hari keempat dan kelima dikarenakan klien yang sedang marah pada ayah karena tidak bisa mengantarkan klien pergi melihat kereta api. Sehingga hal tersebut membuat klien mudah tersinggung yang menyebabkan klien meukul teman dan mengacak meja gurunya.Namun, perilaku memukul menurun pada hari selanjutnya karena guru memarahi dan mengingatkan klien bahwa tidak boleh memukul.Gambar 3.

Pemberian token untuk klien dapat mengurangi perilaku memukul klien ketika disekolah.Dari yang awalnya rata-rata per hari ketika di sekolah dapat mencapai 3 kali memukul dalam sehari, setelah pemberian token ekonomi dapat berkurang hingga 1 kali memukul ketika disekolah.

\section{Pembahasan}

Hasil intervensi menunjukkan bahwa terdapat perubahan setelah diberikannya token ekonomi pada klien.Perilaku memukul klien yang pada awalnya rata-rata 3 kali per hari menurun sampai 1 kali memukul.Ketika di sekolah klien masih terprovokasi ketika ada teman yang menganggu ia bermain atau meminjam permainannya sehingga memunculkan perilaku memukul hingga 4 kali. Setelah kejadian tersebut perilaku memukul klien terlihat menurun menjadi 1 kali memukul hingga fase follow up dan ketika ada teman yang menganggu bermain atau meminjam mainannya klien cenderung tidak menghiraukannya. Sehingga dapat diketahui bahwa sebenarnya dalam diri

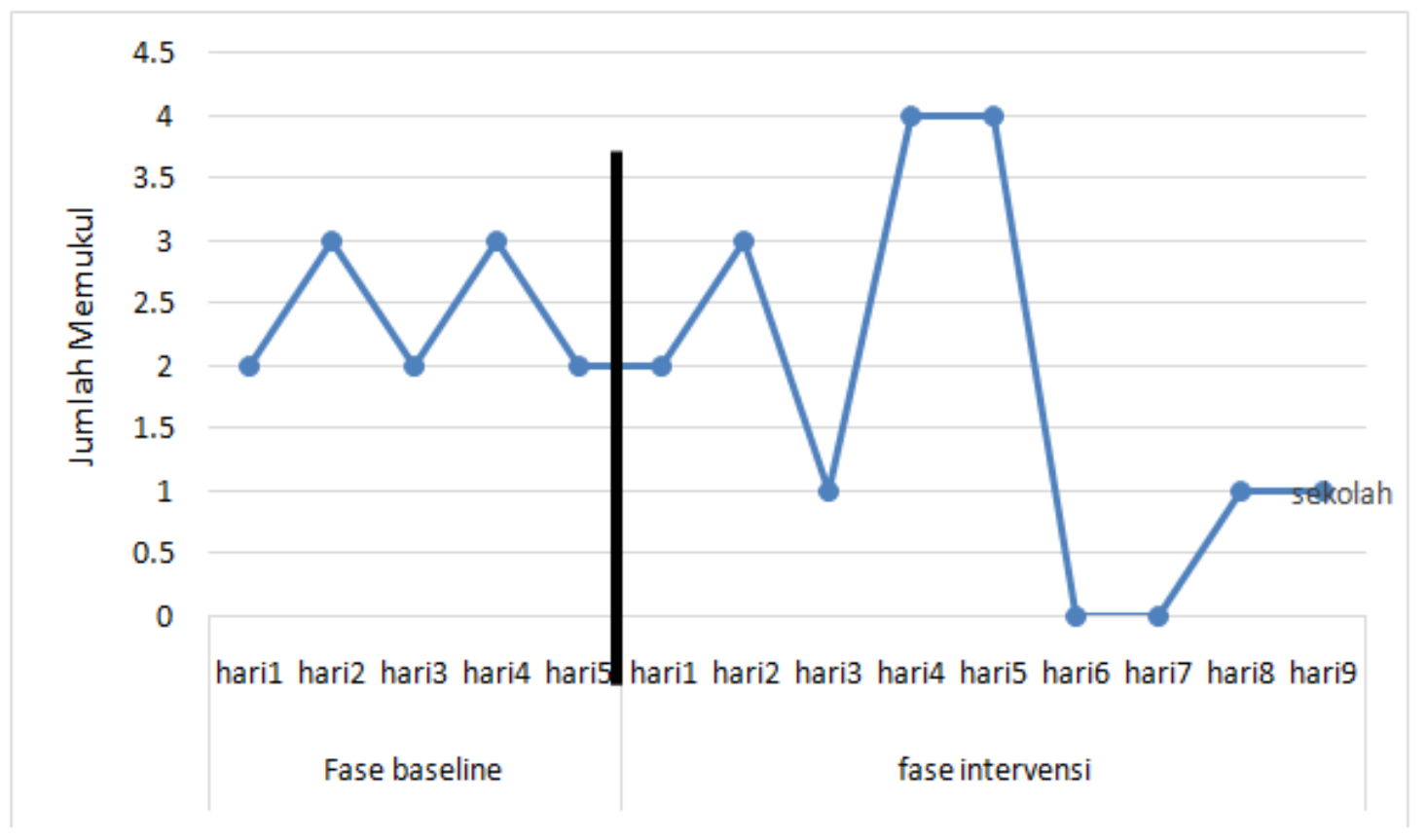

Gambar 3. Perubahan Perilaku Memukul klien. 
klien masih memiliki keinginan untuk memukul namun, dapat di tahan karena orangtua dan guru yang selalu mengingatkan bahwa perbuatan itu tidak baik.

Perubahan yang dialami oleh klien yaitu dengan adanya pemberian token ekonomi.Mulanya klien masih memperlihatkan perilaku memukulnya.Kemudian setelah diberikan perlakuan, sedikit demi sedikit klien mampu menahan untuk tidak menahan dan mengontrol perilaku memukulnya. Ketika klien tahu bahwa klien akan mendapat stempel dan mendapatkan hadiah, dengan senang sehingga klien menurunkan perilaku memukulnya. Kazhim (2010) mengatakan bahwa hadiah adalah wujud penghargaan dan dukungan atas sebuah perilaku yang baik yang dimiliki seorang anak, hadiah juga merupakan sebuah simbol, dengan hadiah anak akan merasakan bahwa perilaku yang didilakukan adalah suatu yang harus dipertahankan.

Kemudian perilaku memukul klien tercatat lebih banyak dilakukan ketika di sekolah di bandingkan ketika klien di rumah. Hal tersebut dikarenakan klien yang masih suka ikut-ikutan temannya untuk menganggu teman yang lain sehingga memunculkan perkelahian. Selain itu, banyaknya interaksi dengan teman-teman lain memunculkan masalah potensial seperti gangguan dari teman atau klien yang terprovokasi oleh teman sehingga memunculkan perilaku memukul. Menurut Martin dan Pear (2003) di dalam prosedur token ekonomi diperlukan adanya penanganan terhadap masalah potensial yang mungkin terjadi dengan cara melakukan perencanaan terlebih dahulu. Dalam hal ini masalah potensial yang ada berasal dari diri dan teman klien yaitu berupa gangguan atau bentuk pelampiasan perilaku.Hal tersebut yang memungkinkan perilaku memukul klien meningkat sampai 4 kali perhari ketika intervensi berlangsung.

Keberhasilan intervensi juga tidak luput dari dukungan ayah dan guru klien untuk mengurangi perilaku memukulnya sehingga klien mampu mengurangi perilakunya.Dukungan dari ayah dan guru dapat dikatakan sebagai penghargaan yang diberikan kepada klien sehingga klien mampu mengurangi perilaku memukulnya.

\section{Kesimpulan}

Berdasarkan hasil intervensi, dapat disimpulkan bahwa terdapat penurunan perilaku memukul pada klien setelah diberikan intervensi berupa token ekonomi.Perilaku memukul yang mulanya rata-rata 3 kali perhari menurun menjadi 1 kali perhari. Dengan demikian dapat dikatakan bahwa intervensi yang dilaksanakan berhasil karena target perilaku yang ditentukan sudah terpenuhi. Sehingga token ekonomi yang diberikan efektif untuk mengurangi perilaku memukul pada klien anak ADHD.

\section{Referensi}

Al Kazhim, N.( 2010). Mendidik Anak tanpakekerasan. Jakarta: Pustaka Al Kautsar

American Psychiatric Association.(2013). Diagnostic and statistical manual of mental disorder edition "DSM-5". Washington DC: American Psychiatric Publishing. Washington DC.

Handayani, T., \& Hidayah, N. (2014).Pengaruh token ekonomiuntuk mengurangi agresivitas pada siswa TK. Fakultas Psikologi, 2(2), 44-52.

Krahe, B. (2005). Perilaku agresif.Yogyakarta; Pustaka Pelajar.

Martin, G. \& Pear, J. (2003).Behavior Modifikation What it is and How to Do it. New Jersey: Prentice Hall,Inc.

Sarafino, E. P. (2012). Applied Behavior Analysis: Principles and Procedures for Modifying Behavior. New Jersey: John Wiley \& Sons.

Saroha., I \& Marlina. (2018). Penggunaan token ekonomiuntuk mengurangi perilaku agresif pada anak dengan gangguan intelektual.Jurnal Penelitian Pendidikan Kebutuhan Khusus. 6 (1): 224-229.

Skinner., B., F. (1953). Science and human behavior. New York: Free Press hal. 65-66.

Slavin., R., E. (2000). Educational Psychology: Theory and practice.person education. New Jersey.

Soekadji., S. (1983). Modifikasi Perilaku: Penerapan sehari-hari dan penerapan profesional. Yogyakarta: Liberty.

Sukhodolsky, D. G., Smith, S. D., McCauley, S. A., Ibrahim, K., \& Piasecka, J. B. (2016). Behavioral interventions for anger, irritability, and aggression in children and adolescents.Journal of Child and Adolescent Psychopharmacology, 26, 1-7. 
Suprihatin., T. (2014). Modifikasi perilaku untuk meningkatkan perilaku memperhatikan pada siswa SD yang mengalami gejala gangguan pemusatan perhatian dan hiperaktivitas (GPPH). Proyeksi. ( (2), 15-36.

Wiramihardja., S., A. (2007). Pengantar psikologi klinis. Bandung: PT. Refika Aditama. 